\title{
Evaluation of the Analgesic and Anti-Inflammatory Potential of Methanolic Leave Extract of Allophylus Africanus Beauv. (sapindaceae)
}

\author{
Zainab Mohammed ${ }^{* 1}$, Fatima Seniere ${ }^{1}$ and Yaro H Abdullahi ${ }^{2}$ \\ ${ }^{1}$ Department of Pharmacognosy and Drug Development, Ahmadu Bello University, Zaria, Kaduna state, Nigeria \\ ${ }^{2}$ Department of Pharmacology and Clinical Pharmacy, Bayero University, Kano, Kano State, Nigeria
}

*Corresponding author: Zainab Mohammed, Department of Pharmacognosy and Drug Development, Ahmadu Bello University,

Zaria, Kaduna state, Nigeria

\begin{abstract}
ARTICLE INFO
Received: 幽 January 29, 2020

Published: 㓞 February 05, 2020

Citation: Zainab Mohammed, Fatima Seniere, Yaro H Abdullahi. Evaluation of the Analgesic and Anti-Inflammatory Potential of Methanolic Leave Extract of Allophylus Africanus Beauv. (sapindaceae). Biomed J Sci \& Tech Res 25(2)-2020. BJSTR. MS.ID.004186.
\end{abstract}

Keywords: Allophylus Africanus; Analgesic; Anti-Inflammation Activities; Phytochemical Constituents; Acute Toxicity

\section{ABSTRACT}

Allophylus africanus BEAV. (Family Sapindaceae) is traditionally used in Northern Nigeria for treating various diseases such as arthritis, ulcers, wounds, diarrhoea, fever and rheumatism without scientific validation. The methanolic leaf crude extract of the plant was investigated for analgesic and anti-inflammatory activities. The analgesic activity was carried out using two models; acetic acid induced writhing and hot plate methods in mice and rats respectively. The anti-inflammatory activity was evaluated using carrageenan induced paw oedema in rats. The results showed that the acetic acidinduced writhing and hot plate model exhibited significant $(\mathrm{p}<0.05)$ analgesic effects at doses of 200 and $400 \mathrm{mg} / \mathrm{kg}$ when compared to control. The results also revealed the extract at $400 \mathrm{mg} / \mathrm{kg}$ body weight significantly $(\mathrm{p}<0.05)$ inhibited formation of paw oedema induced by carrageenan when compared to control. The results obtained were less compared to that of ibuprofen the standard analgesic and anti-inflammatory drug used. Results of the phytochemical screening revealed the presence of carbohydrates, steroids, triterpenes, glycosides, tannins, flavonoids and alkaloids. The acute toxicity study showed the plant to have an $\mathrm{LD}_{50}$ of 3,807 and above $5,000 \mathrm{mg} / \mathrm{kg}$ body weight when administered orally in rats and mice respectively, suggesting that it may be slightly toxic in rats models. The study indicated that $A$. africanus methanolic leaves extract is effective in managing peripheral and centrally induced pain. These results support claims for the folkloric uses of the plant in various communities in Nigeria for treating analgesic and inflammation conditions.

\section{Introduction}

Inflammation and pain are protective responses of living organisms to injury. It is the body's defense reaction of limiting or eliminating the spread of injurious agents. Inflammatory reaction is typically characterized by redness, swelling, heat and pain. Persistent inflammation leads to tissue damage and possible organs failure Chi-ren, et al. [1]. It has been implicated in diseases such as arthritis, cancer, and stroke, as well as in neurodegenerative and cardiovascular diseases Ricciott, et al. [2]. Inflammation occurs in phases, the first phase is characterized by an increase in vascular permeability resulting in fluid exudation from the blood into the interstitial space, the second one by infiltration of leucocytes from the blood into the tissues and the third one by granuloma formation (Chatterjee et al, 2015). Analgesia refers to an ill-defined, unpleasant sensation, which is evoked by external and internal noxious stimulus. Analgesics, which are drugs that act to selectively relieve pain by acting on the CNS or peripheral pain mechanisms without altering consciousness, relieve pain without affecting the cause of pain.

Anti-inflammatory and analgesic therapies for acute and chronic conditions are presently reliant on three major classes of 
drugs: Non-Steroidal Anti-inflammatory Drug (NSAIDS), opoids and a group of drugs collectively called adjuvant, with diverse pharmacological actions. Their undesirable and serious adverse effect has necessitated the search for development of novel safer and more potent alternative analgesic and anti-inflammatory drugs kissin [3]. Therefore, the search for newer and safer analgesic and anti-inflammatory agents from the large array of medicinal plant resources has been intensified Bellik, et al, [4]. Allophylus africanus Beauv. (Family Sapindaceae) is a small tree or shrub with trifoliate leaves, obovate leaflets, dentate margin, serrate or almost entire found in tropical to sub-tropical regions of the world. The flowers are small and creamy-yellow, and the fruit is spherical, fleshy, red to black when ripe Burkill [5]. It is commonly known as 'African false currant', and is well distributed throughout Nigeria with various vernacular names- 'ebe/ukpe'(Esan ),'akanro' / 'akaraesu' (Yoruba), 'akaito' , (Igbo) and 'karki'(Hausa) in Delta, Western, Eastern and Northern Nigeria communities respectively.

Previous phytochemical constituents of A. africanus reported include flavonoids, tannin, saponins and carbohydrates Oladosu, et al. [6]. Various ethnomedicinal uses have been attributed to the plant; the boiled bark, roots and leaves are used to treat aches, fever, and rheumatic pains Sofidiya, et al. [7], twig and root are chewed for teeth cleaning, tooth ache and diarrhoea, leaves and root powder as appetite stimulant, leaves infusion as eye treatment, gout, venereal diseases and sanity, and the root is used as lactation stimulant, abortafacient, dysentery, dropsy and oedema Sofidiya, et al. $[7,8]$. The roots contain tannins that are considered astringent, and are used to treat piles and nose bleeding Agrawal, et al. [9]. For $99 \%$ of the population, chronic inflammation is an affliction of lifestyle which often serves as a precursor for chronic diseases like arthritis (Gil, 2002). In Northern Nigeria, A. africanus is used by traditional medicine practitioners to manage arthritis, diarrhoea and gum diseases of the teeth without scientific validation. The anti -diarrhoeal activity of the plant has being earlier validated by the authors Mohammed, et al. [10]. The aim of this present work is to screen $A$. africamus crude methanolic leaves extract for potential anti-inflammatory and analgesic activities to validate its folkloric claim.

\section{Materials and Methods}

\section{Plant Collection and Identification}

The matured plant material was collected from Samaru village, Zaria, Kaduna State of Nigeria on $18^{\text {th }}$ February, 2015. It was identified by taxonomist, Mal. M. Muhammad of the Department of Biological Sciences, Ahmadu Bello University, Zaria, Nigeria. The authentication was done by comparison with herbarium specimen kept in the herbarium of the same department. The voucher number 1540 has been kept in the Department of Pharmacognosy and Drug Development of the University.

\section{Plant Extraction}

The leaves of A. africanus were removed from the plant, cleaned, air dried under shade at room temperature for a period of 14 days and powdered to suitable size using a mill. A $1 \mathrm{~kg}$ of the powdered leaves was macerated with $2.5 \mathrm{~L}$ of aqueous methanol (20-80\%). for 5 days with occasional shaking, filtered and evaporated to dryness using a Rotary vapor.

\section{Animals}

Locally bred adult albino rats of either sex (150-200g) and Winster mice of either sex (20-30g) used for the biological studies were obtained from the Animal House Facility of the Department of Pharmacology and Therapeutics, Ahmadu Bello University, Zaria, Nigeria. The animals were housed under standard conditions $\left(12 \mathrm{~h} / 12 \mathrm{~h}\right.$ dark/ light cycle, temperature of $37 \pm 2{ }^{\circ} \mathrm{c}$ and 35 $60 \%$ humidity) and fed with standard grower mash (Vital Feeds, Jos, Nigeria PLC) and water ad libitum. All experiments were conducted in the laboratory of the Department of Pharmacology and Therapeutics, Faculty of Pharmaceutical Sciences of Ahmadu Bello University, Zaria, in accordance with guidelines outlined in the Guide for the Care and Use of Laboratory Animals by the National Institute of Health (80-23, revised publication No. 1996). The Animals were acclimatized for one week and also fasted for 18 $\mathrm{h}$ but allowed access to water ad libitum before the experiment was commenced.

\section{Drugs and Chemicals}

All chemicals and drugs used for the experiments were of analytical grade. The drugs used were Carrageenan (Sigma Chemical Co.,USA), pentazocine injection (Pfizer Laboratories), ibuprofen (Rochem International Inc., USA) and acetic acid (SigmaAldrich, USA). Normal saline and methanol (80\%) were obtained from the Department of Pharmacognosy and Drug Development of the University.

\section{Phytochemical Screening}

The phytochemical screening of the leaves of A. africanus was carried out to identify the chemical constituents using standard methods Sofowora, et al. [11,12].

\section{Acute Toxicity Study}

The oral median lethal dose $\left(\mathrm{LD}_{50}\right)$ of the methanolic extract of leaves of $A$. africanus was determined using the method of Lorke [13]. The experiment was conducted in two phases. In the first phase, 9 animals were divided into 3 groups of 3 animals each and administered with the extract in doses of 10,100 and $1000 \mathrm{mg} /$ $\mathrm{kg}$ body weight. The animals were observed for $24 \mathrm{~h}$ for signs of toxicity and death. In the second phase, 4 groups of 1 animal each were administered with graded doses of the extract at 1600, 2900 and $5000 \mathrm{mg} / \mathrm{kg}$ body weight and also observed for signs of toxicity 
and death for $24 \mathrm{~h}$. the $\mathrm{LD}_{50}$ was calculated as the geometric mean of the lowest dose that caused death and the highest dose at which the animals survived.

\section{Tests for Analgesic Activity}

Acetic Acid -Induced Writhing Test in Mice: The peripheral analgesic activity of the leaves extract of $A$. africanus was assessed using the acetic acid-induced writhing as described by Koster, et al. [14]. 30 mice were randomly divided into 5 groups containing 6 animals each $(n=6)$. Group 1 received normal saline $(10 \mathrm{ml} / \mathrm{kg}$ p.o as negative control), group 2 received ibuprofen $(15 \mathrm{mg} / \mathrm{kg}$ body weight (positive control), groups 3,4 and 5 received the different doses of leaves extract $(100,200,400 \mathrm{mg} / \mathrm{kg}$, p.o) respectively. One-hour post drug and vehicle administration, the animals were administered with $(0.6 \% \mathrm{v} / \mathrm{v})$ of the acetic acid in water at dose of $10 \mathrm{ml} / \mathrm{kg}$ body weight (Donkor et al, 2013) to induce pain sensation. The number of abdominal writhing was counted for each animal 5 minutes after acetic acid injection for observation time of 10 minutes. The percentage inhibition of writhing was calculated using the formula:

Inhibition (\%) =Mean no. of writhes (control) - Mean no. of writhes (Test) / Mean no. of writhes (control) X 100. A decrease in the number of writhes is indicative of analgesic effect when compared to control.

Hot Plate Test: The method of Ior, et al. [15] was adopted for the experiment. The animals were firstly exposed to electrical heatinduced nociceptive pain stimulus. Animals that stayed for more than 15 seconds on the hot plate were considered to have impaired nociception and therefore excluded. The mice were randomly divided into 5 groups of 6 animals each $(n=6)$. Group 1 served as control and received normal saline $(10 \mathrm{ml} / \mathrm{kg})$, groups $2,3,4$ and 5 received the standard drug pentozocine $(5 \mathrm{mg} / \mathrm{kg})$ body weight, methanolic extract at doses of 100,200 and $400 \mathrm{mg} / \mathrm{kg}$ body weight respectively. 30 minutes post treatment, the pretreated animals were kept individually in a glass beaker kept on a hot plate maintained at constant temperature of $55 \pm 1^{\circ} \mathrm{C}$. The time taken by the animals for either paw licking or jumping was recorded and taken as the latency to pain response. The latency response was taken as 30 seconds in the control and repeated at intervals of 30 , 60 and 90 minutes post treatment.

\section{Test for Anti-Inflammatory Screening}

Carrageenan Induced-Paw Oedema: The method of Winter, et al. [16] was adopted for the evaluation of the anti-inflammatory of $A$. africanus. In this experiment, 30 adult rats were divided into 5 groups of 6 animals each $(n=6)$. Group 1 was orally administered with normal saline $(10 \mathrm{ml} / \mathrm{kg})$ as negative control, groups $2,3,4$ and 5 received ibuprofen $(15 \mathrm{mg} / \mathrm{kg})$ as positive control, $100 \mathrm{mg} /$ $\mathrm{kg}, 200 \mathrm{mg} / \mathrm{kg}$ and $400 \mathrm{mg} / \mathrm{kg}$ body weight of plant extract orally respectively. 30 minutes post administration, $0.1 \mathrm{~mL}$ of freshly prepared sterile saline suspension of carrageenan ( $1 \% \mathrm{w} / \mathrm{v}$ in $0.9 \%$ normal saline) was injected into the sub plantar surface of the left hind paw of all animals in each group. The hind paw size (oedema) was measured with the aid of a vernier caliper at time zero (0) $\mathrm{hr}$ and at 1, 2, 3, 4 and $5 \mathrm{hr}$ intervals post carrageenan administration. The percentage of inhibition of oedema was calculated using the formula:

Mean increase in paw volume of control- Mean increase in paw volume of treated /Mean increase in paw volume of control X 100.

\section{Statistical Analysis}

The results were expressed as Mean \pm Standard Error of Mean (SEM) and analyzed by one way analysis of variance (ANOVA). The data was statistically analyzed using Student's t-test and the results obtained were compared with the control group with $\mathrm{p}$ values < 0.05 considered to be statistically significant.

\section{Results}

\section{Preparation of Extract}

The crude extract of $A$. africanus recovered after extraction was $60.5 \mathrm{~g}$ of a dark green coloured mass with pleasant odour.

\section{Phytochemical Screening}

The results of the phytochemical screening of the methanolic leaves extract of $A$. africanus showed the presence of secondary metabolites namely, alkaloids, carbohydrates, tannins, steroids, triterpenes, flavonoids and cardiac glycosides. There was absence of saponins (Table 1).

Table 1: Results of phytochemical screening of methanolic extract of A. africanus.

\begin{tabular}{|c|c|}
\hline Constituents & Inference \\
\hline Carbohydrates & + \\
\hline Tannins & + \\
\hline Steroids & + \\
\hline Terpenes & + \\
\hline Flavonoids & - \\
\hline Saponin & + \\
\hline Cardiac glycosides & + \\
\hline
\end{tabular}

Note: $(+)=$ positive,$(-)=$ negative

\section{Acute Toxicity Studies}

The oral $\mathrm{LD}_{50}$ values of the methanolic extract of $A$. africanus leaves in rats and mice were 3,807 and above $5,000 \mathrm{mg} / \mathrm{kg}$ respectively.

\section{Analgesic Studies}

The results of the acetic acid induced writhing test of the methanolic extract of $A$. africanus are shown on Table 2. The results showed a significant $(\mathrm{p}<0.05)$ reduction of the number of writhes by mice compared to control. The highest activity resided at the higher dose of $400 \mathrm{mg} / \mathrm{kg}$ body weight (57.06\%), while the highest activity was observed in the reference drug, ibuprofen (61.90\%). 
Table 2: Results of methanolic extract of A. africanus on acetic acid induced writhing in mice.

\begin{tabular}{|c|c|c|c|}
\hline Treatment & Dose $(\mathbf{m g} / \mathbf{k g})$ & Mean no. of Writhes ( \pm S.E.M) & \% Inhibition \\
\hline Normal saline & $10 \mathrm{ml} / \mathrm{kg}$ & $35.40 \pm 0.53$ & - \\
\hline Ibuprofen & $15 \mathrm{mg} / \mathrm{kg}$ & $13.50 \pm 0.45$ & $61.90^{*}$ \\
\hline Extract & $100 \mathrm{mg} / \mathrm{kg}$ & $32.25 \pm 0.57$ & 8.90 \\
\hline Extract & $200 \mathrm{mg} / \mathrm{kg}$ & $28.42 \pm 0.42$ & 19.72 \\
\hline Extract & $400 \mathrm{mg} / \mathrm{kg}$ & $15.20 \pm 0.62$ & $57.06^{*}$ \\
\hline
\end{tabular}

Note: *=Significant at $\mathrm{P}<0.05$ compared to control.

\section{Hot Plate Test}

In the hot plate test in mice, the methanolic extract of $A$. africanus significantly $(\mathrm{p}<0.05)$ increased the pain reaction time in rats (Table 3). The extract at 200 and $400 \mathrm{mg} / \mathrm{kg}$ significantly $(p<0.05)$ increased the after-treatment reaction time. The $200 \mathrm{mg} /$ $\mathrm{kg}$ increased the mean reaction time at 120 minutes, while the standard drug, Pentazocine and extract at $400 \mathrm{mg} / \mathrm{kg}$ also produced significant $(p<0.05)$ increased mean reaction time at the $30,60,90$ and 120 minutes compared to control.

Table 3: Effect of methanolic extract of A. africanus on pain reaction time in hot plate test in mice.

\begin{tabular}{|c|c|c|c|c|c|}
\hline \multirow{2}{*}{ Treatment } & \multirow{2}{*}{ Dose (mg/kg) } & \multicolumn{4}{|c|}{ Time needed for response after treatment } \\
\hline & & 30 & 60 & 90 & 120 \\
\hline Normal saline & $10 \mathrm{ml} / \mathrm{kg}$ & $3.2 \pm 0.24$ & $2.90 \pm 0.54$ & $2.5 \pm 0.61$ & $2.1 \pm 0.48$ \\
\hline Pentazocine & 5 & $5.2 \pm 0.51^{*}$ & $5.8 \pm 0.30^{*}$ & $5.8 \pm 0.64^{*}$ & $5.9 \pm 0.55^{*}$ \\
\hline Extract & 100 & $3.3 \pm 0.19$ & $3.2 \pm 0.32$ & $3.0 \pm 0.31$ & $3.0 \pm 0.38$ \\
\hline Extract & 200 & $4.0 \pm 0.26$ & $4.1 \pm 0.40$ & $4.4 \pm 0.30^{*}$ & $5.0 \pm 0.20^{*}$ \\
\hline Extract & 400 & $4.6 \pm 0.31^{*}$ & $4.9 \pm 0.45^{*}$ & $5.3 \pm 0.32 *$ & $5.6 \pm 0.30^{*}$ \\
\hline
\end{tabular}

Note: *=Significant at $\mathrm{P}<0.05$ compared to control

\section{Anti-Inflammatory Studies}

In the carrageenan induced hind paw oedema test in rats, sub plantar injection of $0.1 \mathrm{ML}$. of $1 \%$ carrageenan suspension produced local oedema reaching its maximum at the $3^{\text {rd }}$ hour. Results showed a significant $(\mathrm{p}<0.05)$ inhibition in paw oedema in the tested dose of $400 \mathrm{mg} / \mathrm{kg}(50.6 \%)$ in the $3^{\text {rd }}$ hour when compared with control. The anti-inflammatory activity was observed to be more in the reference drug (69.8\%) (Table 4).

Table 4: Effect of the methanolic extract of $A$. africanus on carrageenan- induced rat paw oedema.

\begin{tabular}{|c|c|c|c|c|c|c|c|}
\hline \multirow{2}{*}{ Treatment } & \multirow{2}{*}{ Dose (mg/kg) } & \multicolumn{6}{|c|}{ Mean Paw Oedema $(\mathrm{cm}) \pm S . E . M(\mathrm{~cm})$} \\
\hline & & 1hr & $\%$ & $2 \mathrm{hrs}$ & $\%$ & 3hrs & $\%$ \\
\hline Normal saline & $10 \mathrm{ml} / \mathrm{kg}$ & $1.95 \pm 0.34$ & - & $2.25 \pm 0.56$ & - & $2.45 \pm 0.42$ & - \\
\hline Ibuprofen & $15 \mathrm{ml} / \mathrm{kg}$ & $0.92 \pm 0.20$ & $53 *$ & $0.94 \pm 0.32$ & $69.5^{*}$ & $0.74 \pm 0.24$ & $69.8^{*}$ \\
\hline Extract & $100 \mathrm{ml} / \mathrm{kg}$ & $1.80 \pm 0.22$ & 7.7 & $1.74 \pm 0.14$ & 22.6 & $1.72 \pm 0.25$ & 30.2 \\
\hline Extract & $200 \mathrm{ml} / \mathrm{kg}$ & $1.55 \pm 0.22$ & 21 & $1.72 \pm 0.25$ & 25.7 & $1.47 \pm 0.22$ & 40 \\
\hline Extract & $400 \mathrm{ml} / \mathrm{kg}$ & $1.32 \pm 0.03$ & 32.3 & $1.44 \pm 0.72$ & $42.2^{*}$ & $1.21 \pm 0.05$ & $50.6^{*}$ \\
\hline
\end{tabular}

Note: *=Significant at $\mathrm{P}<0.05$ compared to control.

\section{Discussion}

The present study was aimed at investigating the analgesic and anti-inflammatory activities of the methanol leaf extract of $A$. africanus and establish the oral acute toxicity and phytochemical profiles. Phytochemical screening of the leave extract of $A$. africanus revealed alkaloids, carbohydrates, tannins, steroids, triterpenes, flavonoids and cardiac glycosides. The results obtained conform to the findings of Oladosu, et al. [6] These phytochemical constituents are physiologically active with potential for therapeutic and prophylactic uses. Flavonoids and tannins have been reported to have analgesic and anti-inflammatory effects Ahmadiani, et al. [17] and these may be responsible for the analgesic and antiinflammatory activities of the plant extract observed in this study. Pain and inflammation are complementary and always occur together. The oral $\mathrm{LD}_{50}$ of $A$. Africana was found to be $3,807 \mathrm{mg} / \mathrm{kg}$ and above $5,000 \mathrm{mg} / \mathrm{kg}$ respectively in rats and mice. Based on the toxicity classification of Matsumara, et al. $[18,19]$ this could suggest that the methanolic leaves extract of $A$. africanus is relatively safe in mice but slightly toxic in rats. Scientifically, acute toxicity test gives an idea of the long term effect on body organs and systems when the drug is used. 
In the acetic acid writhing test, the extracts inhibited the writhing reflex in mice. The test is used to screen plants for peripheral analgesic activity Abhimany, et al. [20].The method, also called abdominal constriction response, is very sensitive and able to detect analgesic effects of compounds at dose level that may be inactive in other methods like the tail-flick test Collier, et al. $[21,22]$. The abdominal constriction responses are postulated to partly involve local peritoneal receptors Bentley, et al. [22] and prostaglandins increase in peritoneal fluid (Deradt et al, 1980). The mechanism of activity of the extract may be due to cyclooxygenases inhibition Ior, et al. [15]. The intraperitoneal injection of acetic acid produces abdominal constriction as a result of sensitization of chemo-sensitive nociceptors by prostaglandins Sutharson et al. [23]. The ability of the plant extract to decrease the mean number of abdominal writhes may therefore be due to its action on visceral receptors that are sensitive to acetic acid. Results of the hot plate test showed that $A$. africanus extract significantly increased the pain reaction time of the rats on the hot plate at a higher dose. The hot plate test model is used for the assay of drugs effect on central pain, and drugs that are effective in this model have central analgesic effect Vanita, et al. [24].

The method was adopted to evaluate the extract for possible centrally mediated analgesic effect MacDonald et al. [25]. The central analgesic drug, pentazocine was therefore used as reference drug. The ability of the extract to prolong the thermally induced pain reaction time in mice suggested central analgesic activit. The results of the anti-inflammatory activity showed that $A$. africanus have significant anti-inflammatory activity on carrageenan induced inflammation when compared with control which showed progressive increase in the paw circumference of the rats. The activity was significant and dose dependent in the $3^{\text {rd }}$ hour post injection of the inflammatory agent. Carrageenan induced inflammation is believed to be biphasic- the early phase (1-2 hours) which is mainly mediated by histamine, serotonin and increased prostaglandin release and the late phase (2-5 hours) mediated by bradykinin, polymorphonuclear cells, leukotrienes and prostaglandins produced by macrophages in the tissue Brito, et al. [26]. The extract showed inhibitory effect on the carrageenan -induced inflammation at the end of the $3^{\text {rd }}$ hour which is similar to the effect of most non-steroidal anti-inflammatory drugs. This suggests that the activity of the extract is in the later phase, which could be due to arachidonic acid metabolites leading to oedema dependent on neutrophils mobilizatio. This suggests that methanolic extract of A.africanus has anti-inflammatory effect and would be useful in managing inflammatory pain.

\section{Conclusion}

The work concludes that leave extract of A. africanus has potential analgesic and anti-inflammatory activities. The above results support the folkloric uses of $A$. africanus for treating various forms of pains and inflammatory conditions such as rheumatism, arthritis and fever by traditional medicine practitioners in
Northern Nigeria. Further studies is however necessary to establish the probable mechanism of action for the analgesic and antiinflammatory activities and to isolate the bioactive compounds responsible for the activities.

\section{Acknowledgement}

The authors wish to acknowledge the contribution of the laboratory staff of the Department of Pharmacology and Therapeutics in carrying out the screening for analgesic and antiinflammatory activities.

\section{References}

1. Chi-ren L, Chun-Pin K, Wen-Huang P, Yuan-Shiun C, Shang-Chih I, et al. (2012) Analgesic and anti-inflammatory activities of methanol extract of Ficus pumila L. in mice. Evidence-Based Complementary and Alternative Medicine.

2. Ricciotti E, Fitz Gerald GA (2011) Prrostaglandins and inflammation. Arteriosclerosis Thrombosis Vascular Biol 31(5): 986-1000.

3. Kissin I (2010) The Development of new analgesic over the past 50 years: A lack of real breakthrough drugs. Anesthesia and Analgesia 110 (3): 780-789.

4. Bellik Y, Laid B, Hasan AA, Balkees AB, Fatiha A, et al. (2013) Molecular Mechanism Underlying Anti-inflammatory and Anti-allergic Activities of Phytochemicals: An update. Molecules 18(1): 322-353.

5. Burkill HM (1985) The useful plants of west tropical Africa. London Royal Botanical Garden Kew. pp. 181-182.

6. Oladosu IA, Balogun SO, Ademowo GO (2013) Phytochemical screening antimalarial and histopathological studies of Allophylus africanus and Triagia benthamii Chin J Nat Med 11(4): 371-376.

7. Sofidiya MO, Odukoya OA, Afolayan AJ, Familoni OB (2007) Survey of anti-inflammatory plants sold in herb markets in Lagos Nigeria. International Journal of Botany 3: 302-306.

8. Idu M, Umweni AA, Odaro T, Ojelede L (2009) Ethnobotanical plants used for oral Health care among the Esan tribe of Edo State Nigeria. Ethnobotanical leaflets 13: 548-563.

9. Agrawal VS (1997) Drug plants of India. Kalyani Publishers Ludhiana India pp. 171.

10. Mohammed Z, Seniere F, Abubakar AZ, Yaro A (2017) Anti-diarrhoeal activity of the methanolic extract of leaves of Allophylus africanus Beauv. (Sapindaceae) in mice. Journal of Pharmacology and Tropical Therapeutics 7(1): 50-58.

11. Sofowora A (1993) Medicinal Plants and Traditional Medicine in Africa. Spectrum books Ltd Ibadan ( $\left.2^{\text {nd }} E d n\right) . p p .150-153$.

12. Evans WC (2009) Trease and Evans Pharmacognosy (16 ${ }^{\text {th }}$ Edn). Elsevier.

13. Lorke D (1983) A new approach to acute toxicity testing. Archives of toxicology 54(4): 275-287.

14. koster R, Anderson M, DE Bear EJ (1959) Acetic acid for analgesic screening. Federation proceedings 18: 412-416.

15. Ior LD, Uguru MO Olotu PN, Ohemu TL, Ukpe A (2011) Evaluation of analgesic and anti-inflammatory activities and phytochemical screening of the leaves extract of Paullinia pinnata (Sapindaceae). Journal of Chemical and Pharmaceutical Research 3(4): 351-356.

16. Winter CA, Risley EA, Nuss GW (1962) Carrageenan induced edema in hind paw of the rats as an assay for anti-inflammatory drugs. Proceeding of the society for Experimental Biology and Medicine 111: 544-547.

17. Ahmadiani A, Fereidoni M, Semnanian S, Kamalinejad M, Saremi S (1998) Anti-nociceptive and anti -inflammatory effects of Sambucus ebulus rhizome extract in rats. J Ethnopharmcol 61: 229-235. 
18. Matsumara F (1975) Toxicology of Insecticides New York and London. Plenum Press. pp. 24-26.

19. Loomis TA, Hayes AW (1996). Loomis's essentials of toxicology ( $4^{\text {th }}$ Edn) California Academic Press 208-245.

20. Abhimany Y, Pratiksha S (2010) J Chem Pharm Res 2(3): 255-259.

21. Collier HOJ, Dinneen LG, Johnson CA, Schneider C (1968) The abdominal Constriction Response and its suppression by analgesic drugs in the mouse. Brit J Pharmacol 32(2): 295-310.

22. Bentley GA, Newton SH, Starr J (1983) Studies on the anti-nociceptive action of agonist drugs and their interaction with opoid mechanisms. Brit J Pharmacol 79(1): 125-138.

23. Sutharson L, Lila KN, Presanna kk, Shila EB, Rajan VJ (2007) Antiinflammatory and Antinociceptive activities of methanolic extract of the

ISSN: 2574-1241

DOI: $10.26717 /$ BJSTR.2020.25.004186

Zainab Mohammed. Biomed J Sci \& Tech Res

(C) This work is licensed under Creative

Submission Link: https://biomedres.us/submit-manuscript.php leaves of Fraxinus floribunda Wallich. African Journal of Biotechnology 6(5): 582-585.

24. Vanita GK, Ramaiah M, Shashikaladevi K, Veena K, Vaidya VP (2010) Synthesis of urethanes and substituted ureas encompassing naphtho[2.1-b]furan and evaluation their analgesic activity. J Chem Pharm Res 2(6): 258-264

25. Mac Donalds AD, Woolfe G, Bergel F, Morrison AL, Rinderknecht H (1946) Analgesic action of Pethidine derivatives and related compounds. British Journal of Pharmacology 1: 4-1.

26. Brito ARMS, Antonion MA (1988) Oral anti-inflammatory and antiulcerogenic activities of hydro-alcoholic extract and partition fraction of Turnera ulmifolia (Turneaceae). Journal of Ethnopharmacology 61: 215-228.

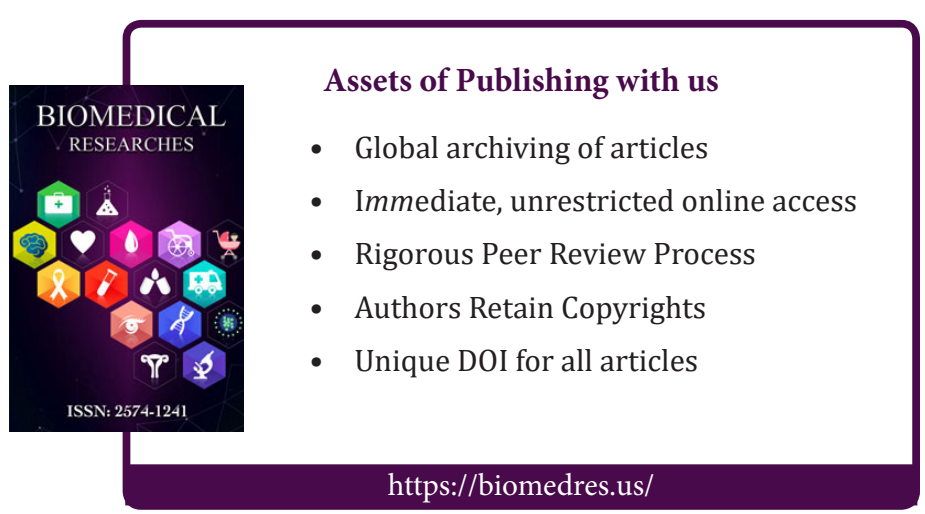

